Article

\title{
New Insight into the Systematics of European Lepidocyrtus (Collembola: Entomobryidae) Using Molecular and Morphological Data
}

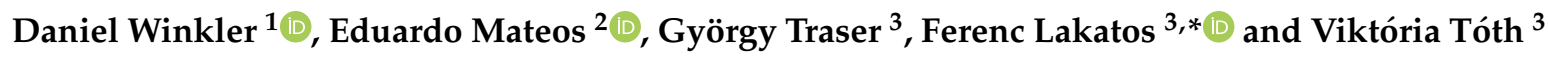 \\ 1 Institute of Wildlife Management and Vertebrate Zoology, Faculty of Forestry, University of Sopron, \\ Bajcsy-Zsilinszky u. 4, H-9400 Sopron, Hungary; winklerdanielandras@gmail.com \\ 2 Departament de Biologia Evolutiva, Ecologia i Ciències Ambientals, Facultat de Biologia, \\ Universitat de Barcelona, Avinguda Diagonal 643, 08028 Barcelona, Spain; emateos@ub.edu \\ 3 Institute of Silviculture and Forest Protection, Faculty of Forestry, University of Sopron, \\ Bajcsy-Zsilinszky u. 4, H-9400 Sopron, Hungary; tgyn49@gmail.com (G.T.); \\ toth.viktoria@uni-sopron.hu (V.T.) \\ * Correspondence: lakatos.ferenc@uni-sopron.hu
}

Received: 6 April 2020; Accepted: 11 May 2020; Published: 13 May 2020

\begin{abstract}
The Collembolan genus Lepidocyrtus is subdivided into up to eight subgenera, of which only Lepidocyrtus s.str. (Bourlet, 1839) and Lanocyrtus (Yoshii \& Suhardjono, 1989) are represented by European species. The discovery of unique characters in the European species Lepidocyrtus tomosvaryi (rounded dental tubercle) and L. peisonis (lateral tuft of long filiform chaetae in abdomen III) has only described so far for species of the subgenera Setogaster (Salmon, 1951) and Cinctocyrtus (Yoshii \& Suhardjono, 1989) and has raised the need to perform a molecular analysis by involving other representative species of the genus. For this study, phylogenetic analysis of 15 Lepidocyrtus species occurring in the Carpathian Basin were carried out. The analyses, which was based on both concatenated datasets of COII and EF1- $\alpha$ sequences and individual gene sequences, clearly placed L. tomosvaryi within the subgenus Lanocyrtus and L. peisonis within Lepidocyrtus s.srt. European species groups defined on the basis of morphological characters were only partly confirmed by the concatenated and COII analyses because of the splitting of the pallidus-serbicus-group, whereas EF1- $\alpha$ sequences weakly supported this group.
\end{abstract}

Keywords: subgeneric division; Ascocyrtus; Cinctocyrtus; Lanocyrtus; Setogaster; COII; EF- $1 \alpha$; phylogeny; taxonomy; cryptic species

\section{Introduction}

Lepidocyrtus (Bourlet, 1839) is considered to be among the most problematic collembolan taxa [1,2]. With 233 species currently reported globally [3], Lepidocyrtus is one of the most species-rich and widespread genera, inhabiting a wide range of habitats from xerophilous areas (e.g., [4,5]) through caves (e.g., [6,7]) to forests (e.g., [8,9]) and wetlands [10]. To date, a total of 35 Lepidocyrtus species have been described in Europe [3], albeit the real number is likely higher considering the probable presence of cryptic species as suggested by several authors [11-15]. The main characteristic features of the genus include $8+8$ eyes, four-segment antennae, body and ventral surface of furcula with scales, and mucro bidentate [16]. After the essential works by Gisin [17-20] and Szeptycki [21,22], accurate information on dorsal cephalic and trunk chaetotaxy became inevitable in the diagnosis of species and species groups. Based on the abovementioned characteristics and the distribution of scales on various parts of the body, five species groups have been defined for European Lepidocyrtus: The lusitanicus-, lignorum-, lanuginosus-, curvicollis-, and pallidus-serbicus-groups, respectively [19,23-28]. 
Nevertheless, the taxonomy of Lepidocyrtus is rather complex and, on the worldwide level, the genus has been subdivided into several subgenera [9,29-33], of which diagnostic characters and their applicability have often been discussed by different authors [34-36]. Of the total of eight currently recognized subgenera (sensu Cipola [9]), only Lepidocyrtus s.str. (Bourlet, 1839) and Lanocyrtus (Yoshii \& Suhardjono, 1989) are represented in the European fauna [13,37]. Both mentioned subgenera are characterized by the absence of a specific morphological feature, the dental tubercle at the basal part of the dens on the dorsal surface, while species belonging to the remaining subgenera possess this morphological character [32]. The vast majority of species with dental tubercle is distributed in the tropical and subtropical regions of East Asia [36].

Surprisingly enough, from Central Europe (Hungary), (Winkler and Traser) [27] described a species, namely L. tomosvaryi (Winkler \& Traser, 2012), having a rounded dental tubercle, a character virtually unknown in any other European Lepidocyrtus species. Based on the subgenera division by Yoshii \& Suhardjono [32], this species should apparently be classified into the subgenus Cinctocyrtus (Yoshii \& Suhardjono, 1989) within the Ascocyrtus group because of the presence of the rounded dental tubercle and the absence of scales on antennae and legs. Nevertheless, its position among the European Lepidocyrtus species has remained uncertain and unclarified. Further curiosity was discovered while examining L. peisonis (Traser \& Christian, 1992), another species originally described from Hungary. On the occasion of its revision and redescription, Winkler and Mateos [38] found a special feature (tuft of filiform chaetae on abdomen III in lateral position) not formerly explored in any European Lepidocyrtus species and which, so far, has only been detected in species of the subgenera Setogaster Salmon, 1951 and Cinctocyrtus [32,38,39]. These two characters (dental tubercle and tuft of long filiform chaetae), observed in the mentioned two species and considered to be unique among the European Lepidocyrtus, evoked a necessity to perform a molecular analysis by involving also other representative species of the genus.

Prior to the present study, Mateos et al. [13] carried out an extensive phylogenetic analysis on Lepidocyrtus, including 19 species from different European localities in order to prove, inter alia, the phylogenetic support of the 5 species groups defined using morphological characters.

The main aims of our study were to (i) reveal the position of the species L. tomosvaryi and L. peisonis with unique morphological features (rounded dental tubercle and lateral tuft of long filaments on abdomen III, respectively) among the European Lepidocyrtus, (ii) clarify the validity of dental tubercle in subgeneric division with respect to the European species, and (iii) ascertain whether the main European species-groups of Lepidocyrtus are supported by our molecular data. In this study, a total of 15 species were included, 8 of which were not present in the work of Mateos et al. [13] on European Lepidocyrtus.

\section{Materials and Methods}

\subsection{Species Sampling and Processing}

From a total of 15 Lepidocyrtus species extracted from samples collected in various habitats (cave, forest, meadows, wetlands) and locations in the Carpathian Basin (Hungary), 77 specimens were studied (Table 1; for specimen codes see Table S1). Specimen collection was partly carried out from surface of soil or stone, lying dead wood, and moss on tree barks using a hand-operated aspirator. Additionally, soil, litter, and moss samples were also collected, from which springtails were extracted using a modified Berlese-Tullgren apparatus without light or heating devices. In case of both methods, specimens were placed in plastic micro tubes filled with $96 \%$ ethanol and tagged with a specific sample code. In the case of four species (L. florae Winkler \& Mateos, 2018, L. isabelleae Winkler 2017, L. tomosvaryi, and L. traseri Winkler 2016), specimens of the type material series were used for the molecular analyses, while specimens of further three species (L. arrabonicus (Traser, 2000), L. mariani (Traser \& Dányi, 2008) and L. peisonis) were collected from the exact type localities. 
Table 1. Collection and locality data of the Lepidocyrtus material examined.

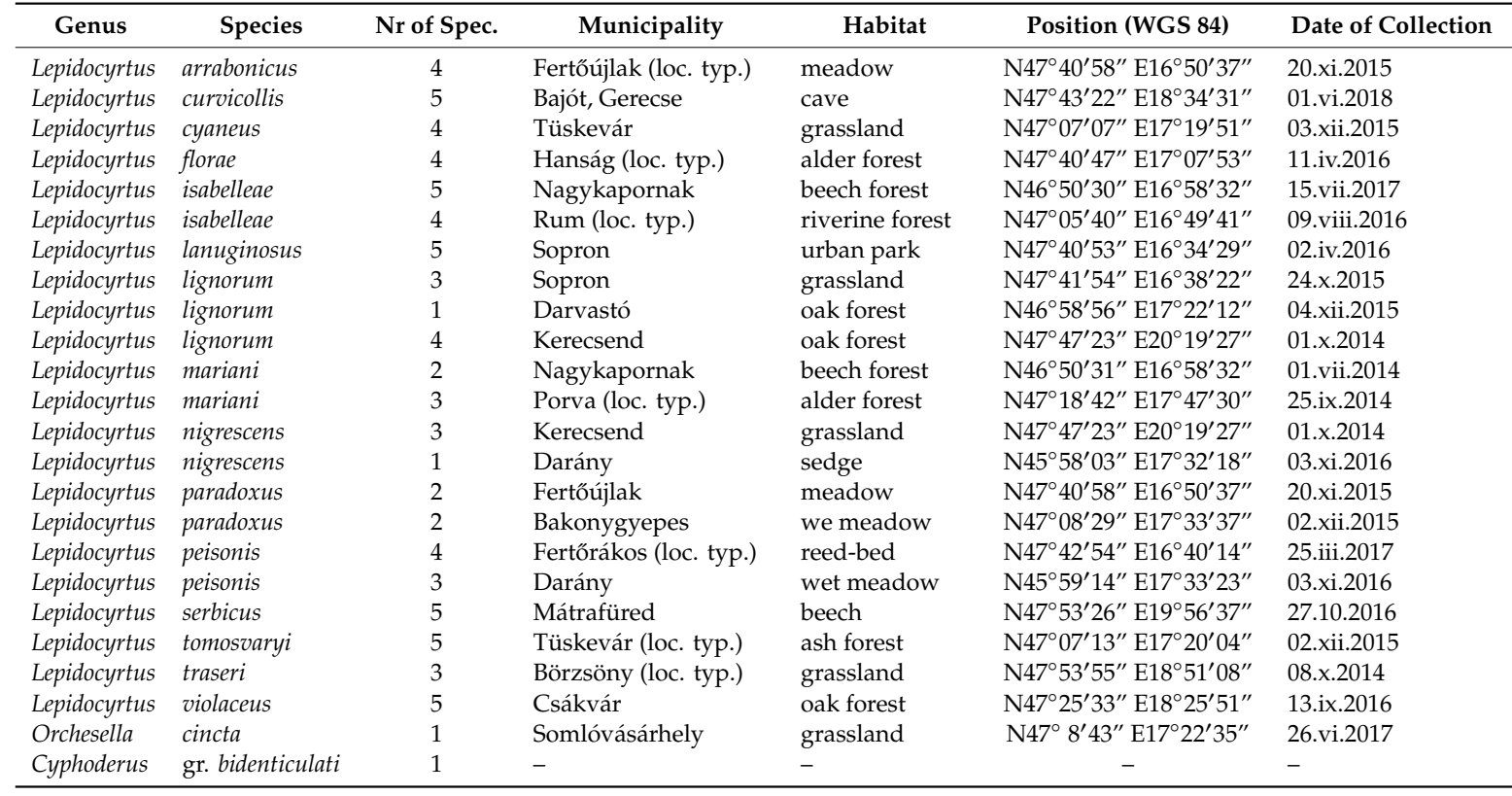

loc. typ.: Specimens collected from the species' type locality.

For morphological analysis, some specimens of each sample were cleared in Nesbitt's solution and mounted in Hoyer medium on glass slides, labeled with the same code of samples in ethanol. The slides were then observed under a Leica DM2500 LED microscope with conventional bright light and phase contrast. The identification of species was performed using relevant keys and descriptions available $[4,24-26,28,37,40]$. Prior to DNA extraction, to ensure identity, specimens selected for molecular analysis were also examined in ethanol for major chaetotaxic characters using a modular Leica M205c stereomicroscope up to 160x magnification.

Of the five European Lepidocyrtus species groups, only four, namely the lignorum-, lanuginosus-, curvicollis-, and pallidus-serbicus-groups, are represented by the species collected and examined in this study (Table 2), since species belonging to the lusitanicus-group are only known from the Iberian Peninsula, Balearic Islands [41] and one locality in the French Pyrenees [42] so far.

The chaetotaxic nomenclature used throughout this paper follows the AMS nomenclature system [35] for dorsal cephalic macrochaetae, and Szeptycki [22] for dorsal schemes of thoracic and abdominal segments.

The following general morphological abbreviations are used: Ant.: Antennal segment; Th.: Thoracic segment; Abd: Abdominal segment; I-VI: Segment numbers; pse: Pseudopores. 
Table 2. Lepidocyrtus species groups and related species examined.

\begin{tabular}{|c|c|c|c|c|c|c|c|c|c|}
\hline Species Group/Species & Head Mac & Body Mac & Scales & Th. II & $\begin{array}{l}\text { Abd. } \\
\text { IV s }\end{array}$ & $\begin{array}{l}\text { Abd. IV } \\
\text { pse (dl-1) }\end{array}$ & $\begin{array}{l}\text { Lateral } \\
\text { Tuft }\end{array}$ & $\begin{array}{l}\text { Dental } \\
\text { Tubercle }\end{array}$ & Unguiculus \\
\hline \multicolumn{10}{|l|}{ L. lanuginosus-group } \\
\hline L. cyaneus & $\mathrm{A}_{0} \mathrm{~A}_{2} \mathrm{~A}_{3} \mathrm{M}_{2} \mathrm{~S}_{3} \mathrm{~Pa}_{5}$ & $10 / 0101+2$ & - & $\mathrm{n}$ & - & - & - & - & $\mathrm{A}$ \\
\hline L. lanuginosus & $\mathrm{A}_{0} \mathrm{~A}_{2} \mathrm{~A}_{3} \mathrm{M}_{2} \mathrm{~S}_{3} \mathrm{~Pa}_{5}$ & $10 / 0101+2$ & - & $\mathrm{n}$ & - & - & - & - & $\mathrm{A}$ \\
\hline \multicolumn{10}{|l|}{ L. pallidus-serbicus group } \\
\hline L. arrabonicus & $\mathrm{A}_{0} \mathrm{~A}_{2} \mathrm{~A}_{3} \mathrm{~Pa}_{5}$ & $00 / 0101+2$ & - & $\mathrm{n}$ & - & - & - & - & A \\
\hline L. florae & $\mathrm{A}_{0} \mathrm{~A}_{2} \mathrm{~A}_{3} \mathrm{~S}_{3} \mathrm{~Pa}_{5}$ & $00 / 0101+2$ & - & $\mathrm{n}$ & - & - & - & - & A \\
\hline L. isabelleae & $\mathrm{A}_{0} \mathrm{~A}_{2} \mathrm{~A}_{3} \mathrm{M}_{2} \mathrm{~S}_{3} \mathrm{~Pa}_{5}$ & $00 / 0101+2$ & - & $\mathrm{n}$ & - & - & - & - & A \\
\hline L. serbicus & $\mathrm{A}_{0} \mathrm{~A}_{2} \mathrm{~A}_{3} \mathrm{M}_{2} \mathrm{~S}_{3} \mathrm{~Pa}_{5}$ & $00 / 0101+2$ & - & $\mathrm{n}$ & - & - & - & - & $\mathrm{A}$ \\
\hline L. tomosvaryi & $\mathrm{A}_{0} \mathrm{~A}_{2} \mathrm{~A}_{3} \mathrm{M}_{2} \mathrm{~S}_{3} \mathrm{~Pa}_{5}$ & $00 / 0101+2$ & - & $\mathrm{n}$ & - & - & - & + & $\mathrm{A}$ \\
\hline \multicolumn{10}{|l|}{ L. lignorum group } \\
\hline L. lignorum & $\mathrm{A}_{0} \mathrm{~A}_{2} \mathrm{~A}_{3} \mathrm{~Pa}_{5}$ & $00 / 0101+3$ & + & $\mathrm{p}$ & - & - & - & - & A \\
\hline L. peisonis & $\mathrm{A}_{0} \mathrm{~A}_{2} \mathrm{~A}_{3} \mathrm{~Pa}_{5}$ & $00 / 0101+3$ & + & $\mathrm{p}$ & - & - & + & - & $\mathrm{T}$ \\
\hline L. traseri & $\mathrm{A}_{0} \mathrm{~A}_{2} \mathrm{~A}_{3} \mathrm{~Pa}_{5}$ & $00 / 0101+3$ & + & $\mathrm{p}$ & - & - & - & - & A \\
\hline L. violaceus & $\mathrm{A}_{0} \mathrm{~A}_{2} \mathrm{~A}_{3} \mathrm{~Pa}_{5}$ & $00 / 0101+3$ & + & $\mathrm{p}$ & - & - & - & - & A \\
\hline \multicolumn{10}{|l|}{ L. curvicollis group } \\
\hline L. curvicollis & $\mathrm{A}_{0} \mathrm{~A}_{2} \mathrm{~Pa}_{5}$ & 00/0101+3 & + & $\mathrm{P}$ & + & + & - & - & A \\
\hline L. mariani & $\mathrm{A}_{0} \mathrm{~A}_{2} \mathrm{~Pa}_{5}$ & $00 / 0101+3$ & + & $\mathrm{P}$ & + & + & - & - & A \\
\hline L. nigrescens & $\mathrm{A}_{0} \mathrm{~A}_{2} \mathrm{~Pa}_{5}$ & $00 / 0101+3$ & + & $\mathrm{P}$ & + & - & - & - & A \\
\hline L. paradoxus & $\mathrm{A}_{0} \mathrm{~A}_{2} \mathrm{~Pa}_{5}$ & 00/0101+3 & + & $\mathrm{P}$ & + & - & - & - & A \\
\hline
\end{tabular}

Head mac: dorsal cephalic macrochaetotaxy; Body mac: dorsal trunk macrochaetotaxy; Scales: Presence (+) or absence (-) of scales on antennae, legs (beyond coxae) and posterior face of manubrium; Th. II: Mesothorax projection-not projecting $(\mathrm{n})$, slightly projecting $(\mathrm{p})$, strongly projecting $(\mathrm{P})$ over the head; Abd. IV s: Presence $(+)$ or absence (-) of accessorial chaeta s on Abd. IV; Abd. IV pse (dl-1): Presence (+) or absence $(-)$ of Abd. IV pseudopores in dorsolateral or lateral position; Dental tubercle: Presence $(+)$ or absence $(-)$ of dental tubercle on the basal part dens (dorsally); Unguiculus: shape of unguiculus-acuminate (A), truncate (T).

\subsection{Molecular Methods}

\subsubsection{DNA Extraction and Sequencing}

All samples were stored in $96 \%$ ethanol at $4{ }^{\circ} \mathrm{C}$ until DNA extraction. Voucher specimens and extracted DNA samples were stored at the institute's collection. DNA was extracted from entire bodies using Thermo Scientific Phire Animal Tissue Direct PCR Kit following the manufacturer's protocol. Eluted DNA was stored at $-20^{\circ} \mathrm{C}$.

A segment of the mitochondrial gene cytochrome oxidase subunit II (COII) was amplified using tRNA-20-LcuJ (5'-GGTTTAAGAGACCGTGGCTTAC- $\left.3^{\prime}\right)$ and tRNA-13-LcuN (5'-TCTAACGTGGCAGACTAGTGC-3'), as well as two additional primers of tRNA-K-LcuJ (5'-GAGCGTATTATAAAGCGGTTTAAG-3') and tRNA-L-LcuN (5'-CAGACTAGTGCCATGAATTTAAGC-3') (11). A fragment of the fragment of the elongation factor-1 alpha (EF1- $\alpha$ ) gene was amplified using EFLcuJ (5'-ATGGGGGCAAGATAGCGTCAA- $3^{\prime}$ ) and EFLcuN (5'-TGAAGGCTGAACGTGAACGTGG - $3^{\prime}$ ) primers [11]. PCR amplifications were performed with Thermo Scientific Phire Hot Start II DNA Polymerase. Thermocycling consisted of an initial denaturation step at $98^{\circ} \mathrm{C}$ for $5 \mathrm{~min}$, followed by 40 cycles at $98{ }^{\circ} \mathrm{C}$ for $5 \mathrm{~s}, 48{ }^{\circ} \mathrm{C}$ for $5 \mathrm{~s}$, and $72{ }^{\circ} \mathrm{C}$ for $20 \mathrm{~s}$ with a final extension step that lasted $1 \mathrm{~min}$ at $72{ }^{\circ} \mathrm{C}$ for the COII gene; $5 \mathrm{~min}$ at $98^{\circ} \mathrm{C}$ followed by 40 cycles at $98^{\circ} \mathrm{C}$ for $5 \mathrm{~s}, 55^{\circ} \mathrm{C}$ for $5 \mathrm{~s}$, and $72{ }^{\circ} \mathrm{C}$ for $20 \mathrm{~s}$ with a final extension step that lasted $1 \mathrm{~min}$ at $72{ }^{\circ} \mathrm{C}$ for the EF1- $\alpha$ gen.

Sequences were generated at the Eurofin's Laboratory (Ebersberg, Germany). All sequences are available at NCBI GenBank (accession numbers: MT136169-MT136241, and MT153249-MT153288, Table S1).

\subsubsection{Data Analyses}

For nuclear DNA (EF1- $\alpha$ ) analyses, 39 individuals were used, and 72 individuals were entered to the mitochondrial DNA (COII) analyses (Table S1). Sequences were visualized using Sequence Scanner and ambiguous positions were corrected by hand. Subsequently, sequences were aligned using ClustalX [43]. Sequences of COII and EF1- $\alpha$ gene fragments were then concatenated, resulting in a 1061-bp-long final alignment. 
Intra- and interspecific divergences of COII and EF1- $\alpha$ were calculated based on K2P [44] and uncorrected p-distances using MEGA 5.02. [45].

\subsubsection{Phylogenetic Analyses}

As outgroups for the phylogenetic analyses, we used Cyphoderus gr. bidenticulati sensu Delamare-Deboutteville [46] data by Mateos et al. [13] taken from the GenBank (MF095527, MF095613) and our own sequences of Orchesella cincta (Linnaeus, 1758). We applied jModeltest 2.1.2 [47,48] to select the best model of nucleotide substitution with Akaike Information Criterion (AIC) [49]. The selected model was HKY $+\mathrm{I}+\mathrm{G}$ for COII, while GTR $+\mathrm{I}+\mathrm{G}$ was the best model for EF1- $\alpha$. In the concatenated alignment, all three coding positions of the COII and EF1- $\alpha$ were included in the analyses, and the best-fitting substitution models were applied for each gene (partition). Maximum likelihood (ML) analysis was performed with MEGA 5.02. [45] in case of the COII and EF1- $\alpha$ dataset. The level of support for individual nodes was evaluated by bootstrapping with 5000 replicates. On the concatenated data set, the maximum likelihood analyses were performed using the software IQ-TREE 1.6.12 [50]. Node support was assessed by 1000 bootstrap replicates.

Bayesian Inference analyses were performed by MrBayes v. 3.2. [51]. A stop rule was applied during the run when the value reached 0.01 , which occurred on the 57,900,000 (COII), 8,610,000 (EF1- $\alpha$ ), and 7,398,000 (concatenated) Markov Chain Monte Carlo (MCMC) generations with two chains. MCMC started from a random tree, sampling one tree every 10,000 generations. The first $25 \%$ of the trees were discarded as a burn-in. To test convergence, the software Tracer v1.7 [52] was used. Effective sample size (ESS) values exceeded 200 for all estimated parameters. Trees from Bayesian analyses were presented using FigTree v. 1.4.4. [53].

\section{Results}

\section{Molecular Analyses}

A total of 72 sequences were obtained for the mitochondrial COII gene with a total length of $552 \mathrm{bp}$ for all 15 species (Table S1). For the nuclear gene EF1- $\alpha, 39$ sequences were gained from 14 species (omitting L. arrabonicus) containing $80 \mathrm{bp}$ of the first exon, 88-124 bp of the intron, and $279 \mathrm{bp}$ of the second exon. Interspecific uncorrected p-distances based on COII (Table S2) ranged from 14.5\% (between L. nigrescens Szeptycki, 1967 and L. paradoxus Uzel, 1890) to 31.0\% (between L. curvicollis Bourlet, 1839 and L. isabelleae). Extreme values of mean K2P distances (Table S3) were observed between the same species pairs, ranging from $16.4 \%$ (between L. nigrescens and L. paradoxus) to $40.8 \%$ (between L. curvicollis and L. isabelleae).

The concatenated phylogenetic tree constructed from the COII and EF1- $\alpha$ genes presented five major clades (Figure 1), only partly corresponding with the morphological species groups as defined in Table 2 because of the splitting of the pallidus-serbicus-group, which appeared as a polytomy of two clades in the upper position of the tree. The species from pallidus-serbicus-group bearing cephalic macrochaetae $\mathrm{A}_{0} \mathrm{~A}_{2} \mathrm{~A}_{3} \mathrm{M}_{2} \mathrm{~S}_{3} \mathrm{~Pa}_{5}$ and with body macrochaetae formula 00/0101+2, namely L. isabelleae, L. serbicus, and the only European species with dental tubercle, L. tomosvaryi (Figure 2a-c), were clustered as sister taxa forming a monophyletic group strongly supported by Bayesian posterior probability $(100 \%)$. L. florae, a species also belonging to the pallidus-serbicus-group but omitting head macrochaeta $\mathrm{M}_{2}$, appeared as sister clade.

The lanuginosus-group, including the species L. cyaneus (Tullberg, 1871), and L. lanuginosus (Gmelin, 1788) and characterized by body macrochaetae formula 10/0101+2, formed a separate clad maximally supported by both BI and ML.

The fourth highly supported clade was formed by the curvicollis and lignorum-groups. A strong support (100\% for both BI and ML, respectively) for the subclade representing the species of the curvicollis-group, namely L. curvicollis, L. mariani, L. nigrescens, and L. paradoxus, was found. Concerning the lignorum-group, the BI method yielded a strong support (93\%), while the ML method provided 
lower (76\%) assignment success for this clade, composed of the species L. lignorum (Fabricius, 1793), L. violaceus (Geoffroy, 1762), L. traseri, and L. peisonis (Figure 3a). Within this clade, populations of the latter species, bearing a lateral tuft of long filiform chaetae (Figure 3b), formed different monophyletic subgroups (L. peisonis 1, L. peisonis 2, and L. peisonis 3 in Figure 1), also suggesting the presence of cryptic species.

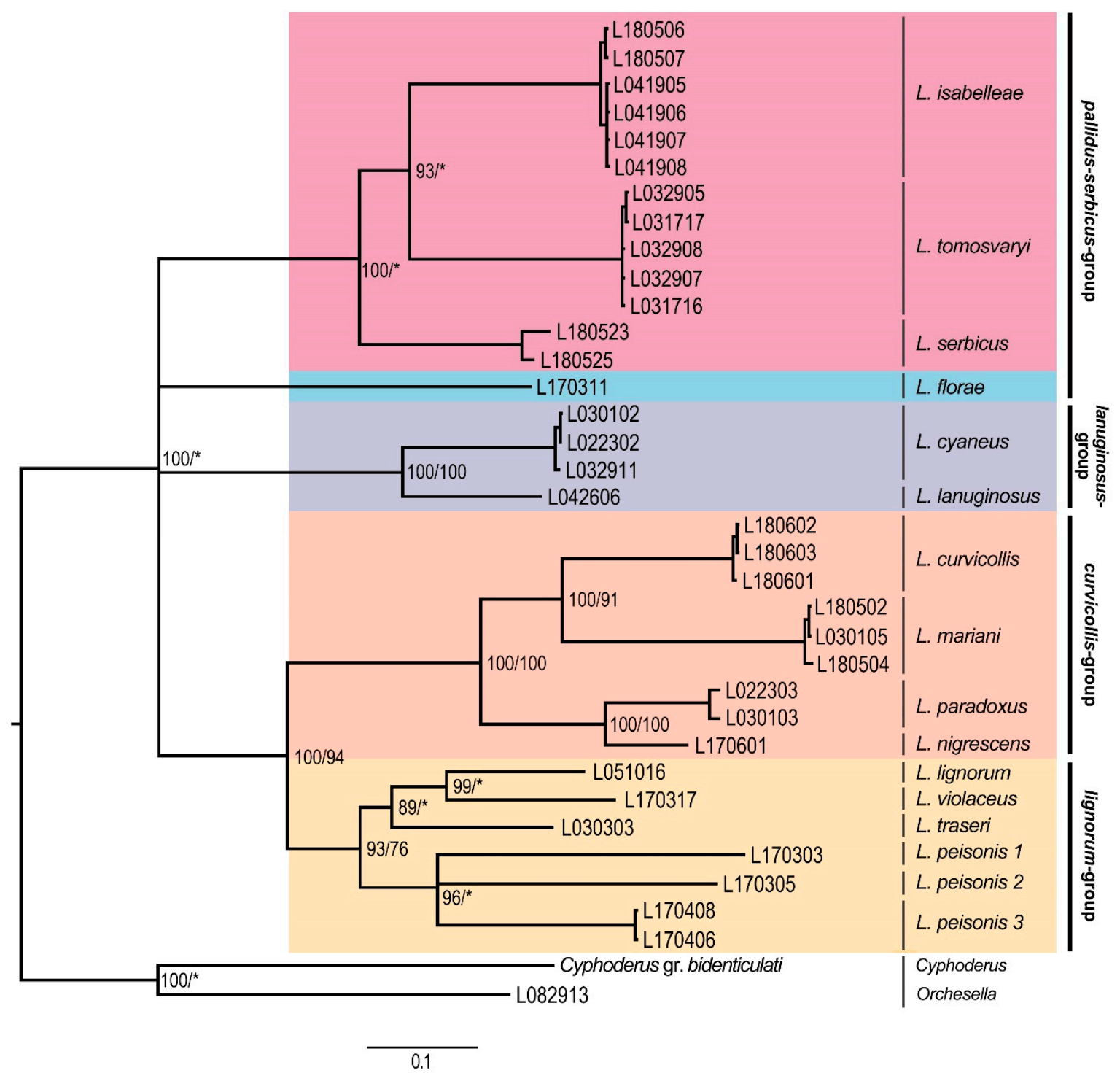

Figure 1. Bayesian consensus tree based on the concatenated (COII and EF1- $\alpha$ ) dataset. Numbers close to nodes denote Bayesian posterior probabilities (BI)/maximum likelihood (ML) bootstrap support. Asterisks $\left.{ }^{*}\right)$ indicate posterior probabilities or bootstrap values less than $60 \%$. Morphological groups are labeled in bold. 

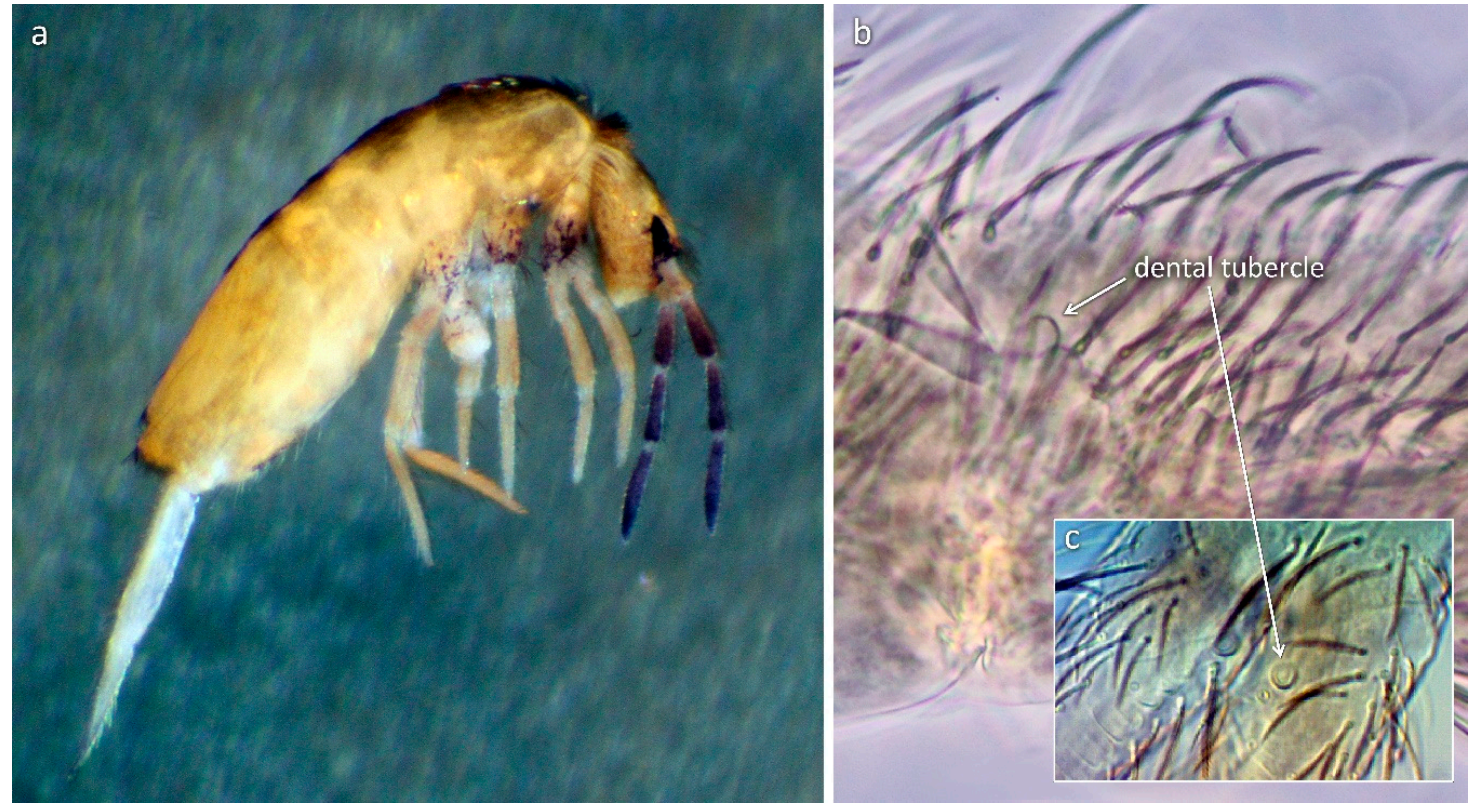

Figure 2. Lepidocyrtus tomosvaryi: (a) Habitus; basal part of dens with rounded dental tubercle in (b) lateral and (c) dorsal view.
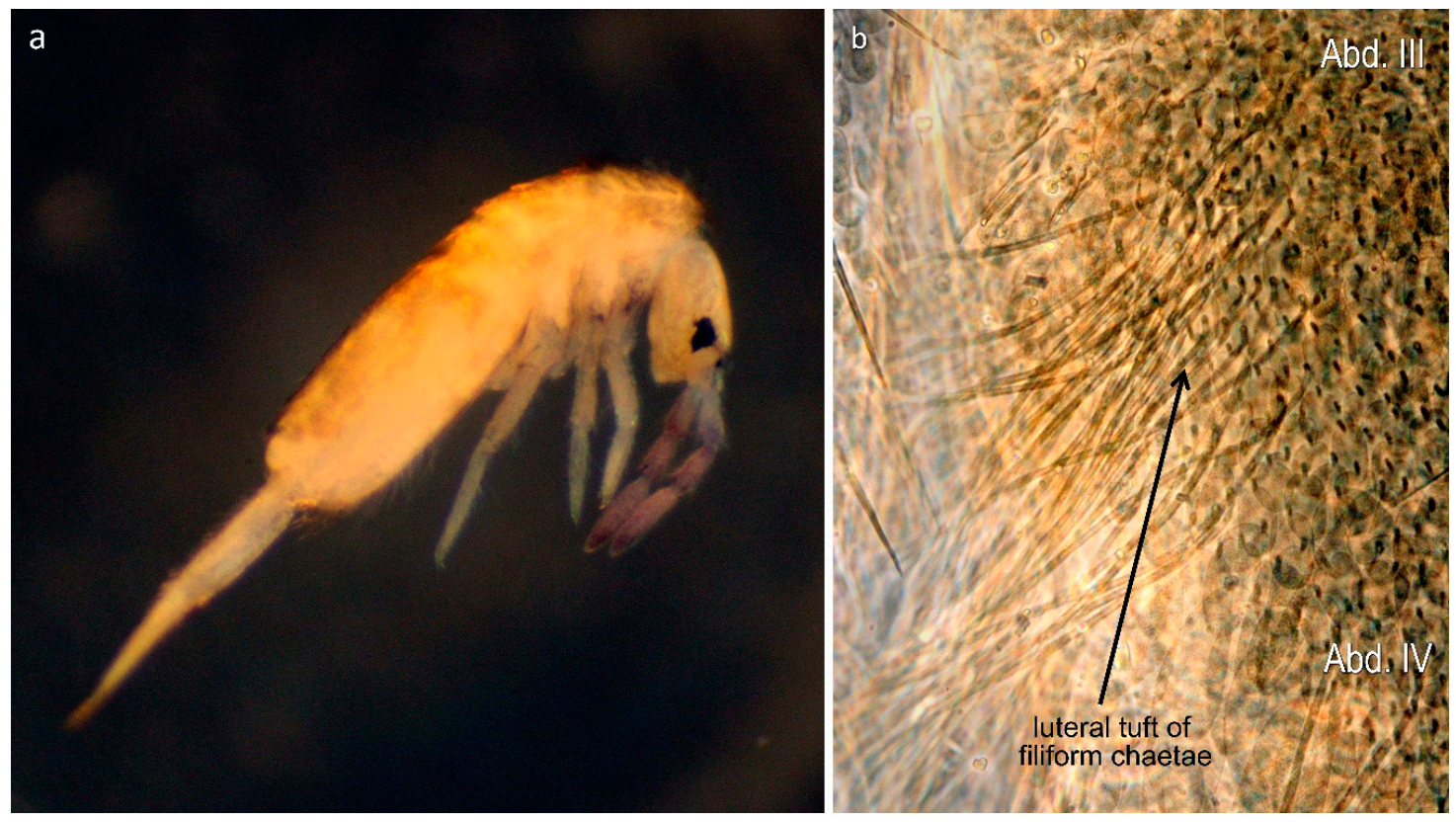

Figure 3. Lepidocyrtus peisonis: (a) Habitus; (b) tuft of filiform chaetae on the lateral part of Abd. III.

Phylogenetic trees of individual genes show slightly different topologies with respect to the topology of the concatenated tree. With reference to the EF1- $\alpha$ phylogenetic tree (Figure 4), the most basal clade corresponded to the lanuginosus-group, forming a highly supported clade. The pallidus-serbicus-group, including L. florae, L. serbicus, L. isabelleae, and L. tomosvaryi, formed a monophyletic but only weakly supported group, as both ML and BI were below $60 \%$. For the curvicollis+lignorum clade, only BI provided strong support. Within this clade, the species of curvicollis-group formed a monophyletic entity with high support, while species of lignorum-group split in two groups. On the one hand, specimens of the L. peisonis populations appeared as a sister clade to the curvicollis-group, despite their morphologic differences (in L. peisonis, Th.II only slightly 
projected, head macrochaeta A3 is present, while Abd. IV accessory chaeta s is absent, see Table 2). However, only BI yielded decent support (71\%) for this topology. On the other hand, the other species of lignorum-group (namely L. lignorum, L. traseri and L. violaceus) appeared as highly supported clade and formed the sister group of the clade formed by the L. peisonis + curvicollis-group.

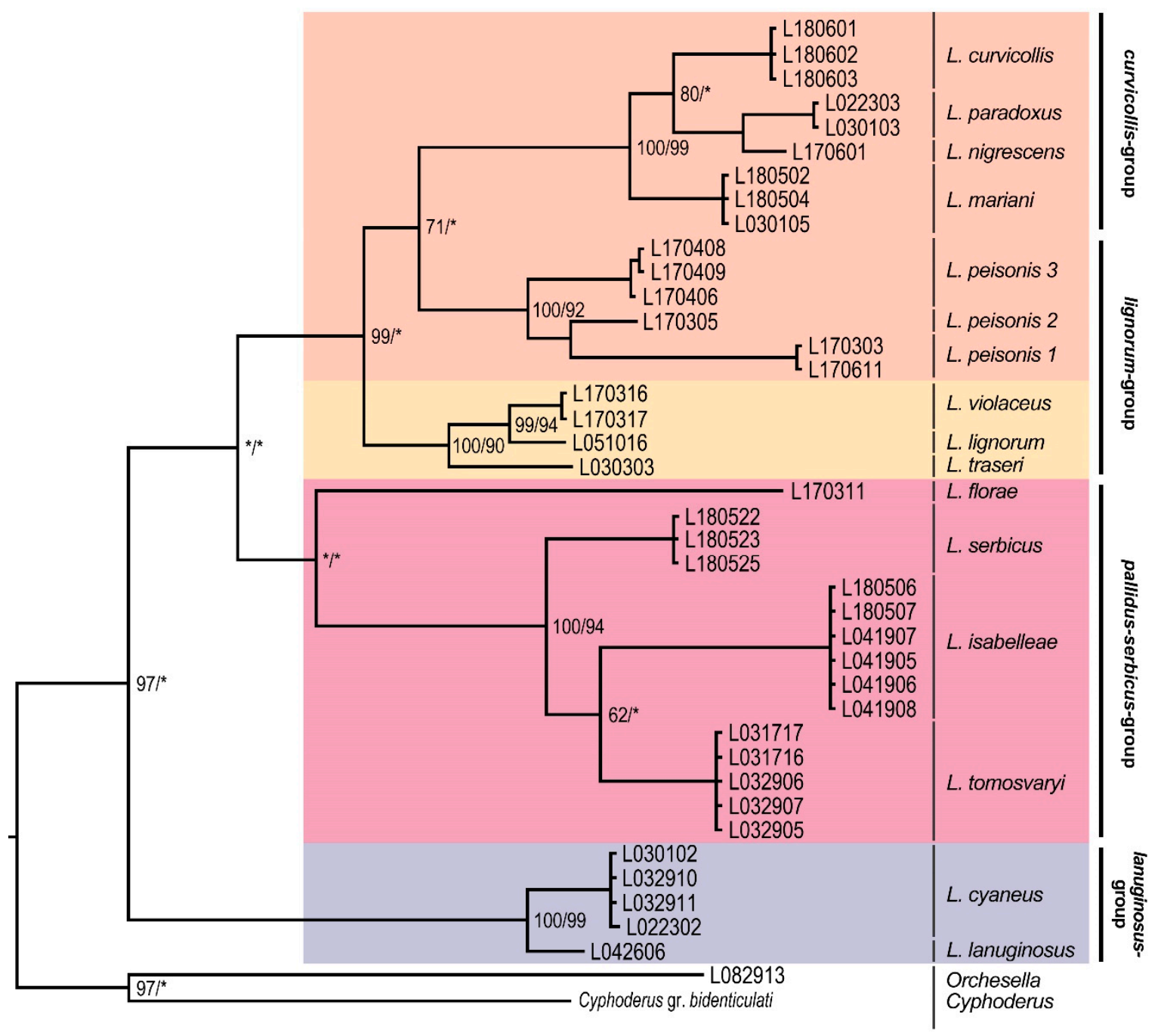

0.1

Figure 4. Bayesian consensus tree obtained based on the EF1- $\alpha$ dataset. Numbers close to nodes denote Bayesian posterior probabilities/maximum likelihood bootstrap support. Asterisks $\left(^{*}\right)$ indicate posterior probabilities or bootstrap values less than $60 \%$. Morphological groups are labeled in bold.

In the COII dataset (Figure 5), the species from the pallidus-serbicus-group were split in two groups. On the one hand, L. arrabonicus and L. florae formed a well-supported clade in the upmost position of the tree, while, on the other hand, L. isabelleae, L. serbicus and L. tomosvaryi formed a well-supported clade located as a sister group of the lanuginosus-group. The curvicollis+lignorum groups formed a clade highly supported by BI. Within this clade, the curvicollis-group appeared as a strongly supported (BI) monophyletic group, while species from the lignorum-group split in several branches. This splitting suggests the presence of cryptic species among the different sampled populations of both L. lignorum and L. peisonis, which is also emphasized by the high mean p-distance and K2P values (14.7 and 16.7 for L. lignorum, and 25.2-26.6 and 31.0-34.0 for L. peisonis, respectively) (Tables S2 and S3). 


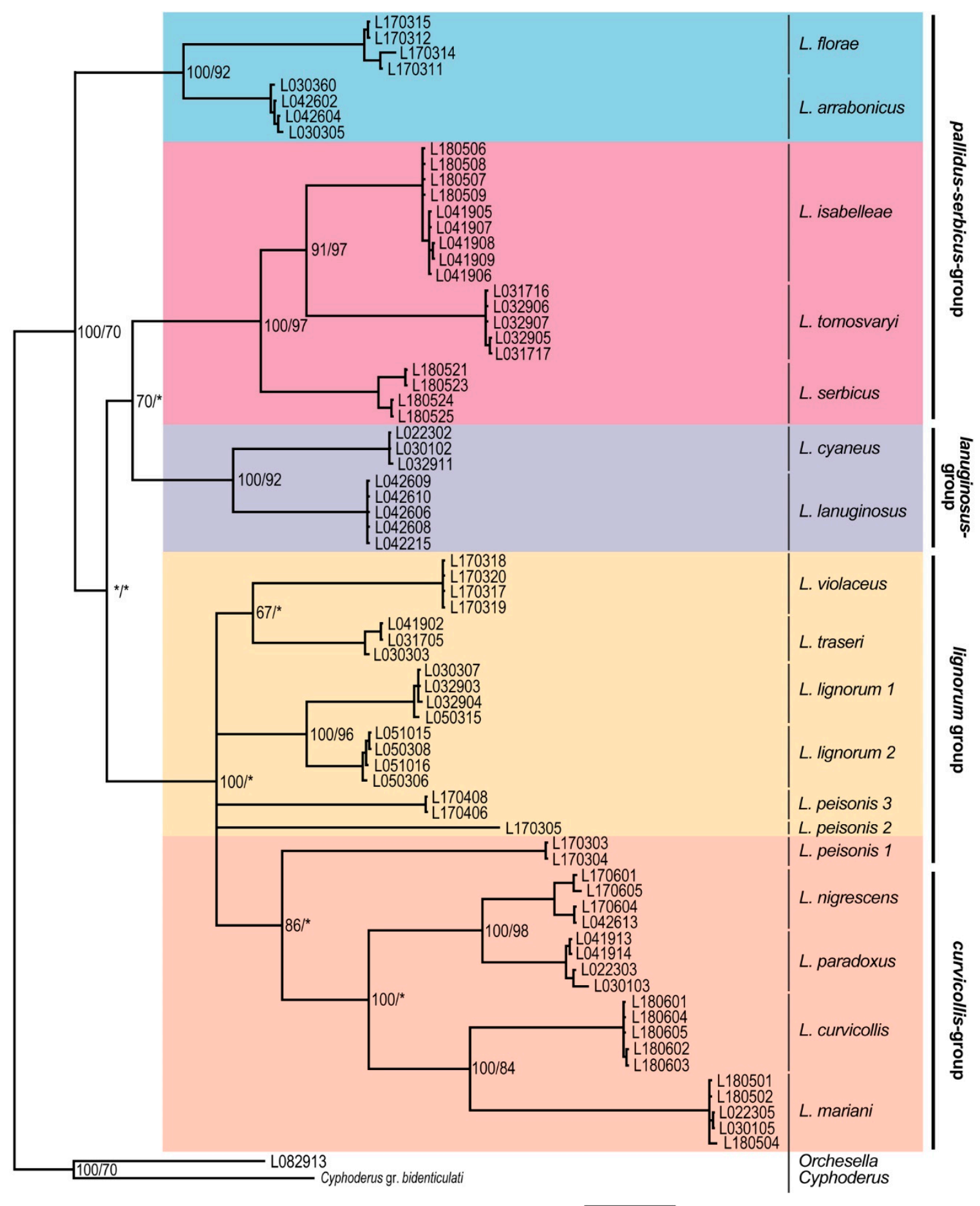

0.1

Figure 5. Bayesian consensus tree obtained based on the COII dataset. Numbers close to nodes denote Bayesian posterior probabilities/maximum likelihood bootstrap support. Asterisks ${ }^{*}$ ) indicate posterior probabilities or bootstrap values less than $60 \%$. Morphological groups are labeled in bold.

\section{Discussion}

The Carpathian Basin is known as one of the areas of highest biodiversity in Europe, owing to the different biogeographic influences [54], which is also well reflected in the rich Collembola fauna [55], including the relatively high number (18) of Lepidocyrtus species reported from Hungary [28]. Among the species occurring in the country, particular attention has been focused to those species 
(L. tomosvaryi and L. peisonis) bearing specific characters mostly typical for Lepidocyrtus inhabiting the tropical and subtropical regions of East Asia, America, or Australia [36,39]. Our molecular study with the supplementary morphological observations could shed light on the identity of these two species, the validity of subgeneric classification within the European Lepidocyrtus, and the conformity of species groups previously established on the basis of morphological characters [23-28].

\subsection{Subgeneric Aspects of the European Lepidocyrtus}

Based mostly on Oriental species, the first subgeneric classification system of the genus Lepidocyrtus was established by Yosii [30], which was subsequently revised and refined [1,9,31,32]. The fundamental determining character in Yoshii's classification is the presence or absence and the shape of the basal dental tubercle. The only two subgenera lacking this feature, which is the subgenera to which all European species belong, are Lepidocyrtus s.str. (Bourlet, 1839) and Lanocyrtus (Yoshii \& Suhardjono, 1989). The only separating character between these two subgenera is the presence of scales on the antennae, legs beyond coxae, and posterior face of manubrium in Lepidocyrtus s.str. and their absence in Lanocyrtus [32]. The species L. tomosvaryi would typically belong to the latter group. However, a marked difference, namely the presence of the dental tubercle, has already raised confusion in assigning the species to a particular subgenus [27]. Due to the presence of a rounded dental tubercle, L. tomosvaryi should apparently be placed in the Ascocyrtus group, more precisely in the subgenus Cinctocyrtus (Yoshii \& Suhardjono, 1989) because of the absence of scales on antennae and femur [32,36]. Based on our molecular analyses, EF1- $\alpha$ sequence data clearly placed L. tomosvaryi among the pallidus-serbicus group and COII data within the serbicus-group sensu (Winkler) [56]. Accordingly, notwithstanding the presence of the dental tubercle, this species has close relation with those lacking this feature but sharing the same body macrochaetotaxy $(00 / 0101+2)$ and distribution of scales, thus belonging to the subgenus Lanocyrtus.

According to our current knowledge, species possessing dental tubercle are mostly distributed in the tropical and subtropical regions of East and Southeast Asia, America, and Australia $[1,35,39,57,58]$, whereas they rarely occur in the temperate zone [36]. This fact raises the possibility that the presence of the dental tubercle, apart from the geographic explanation, is of climatic origin [36]. Nevertheless, this assumption was weakened by the occurrence of a species possessing this feature in the temperate continental region (Central Europe). Wang et al. [36] drew attention to a morphological difference of dental tubercle between the Oriental species, where the tubercle is usually distinct with a clear basal socket, and species outside the Asian region, where this papilla is generally less clear from a barely observable hump to a clear projection, but almost never having any sort of basal socket. L. tomosvaryi, however, does not fall into the latter category, since a clear basal socket of the dental tubercle is easily observable (Figure 2c).

Whereas the taxonomic relevance of the basal dental tubercle as subgeneric diagnostic character has been proven, its validity and applicability on worldwide level has been often questioned [34,36]. Based on a phylogenetic analysis of Hawaiian Lepidocyrtus, the basal dental tubercle was found to be less determinative in delineating monophyletic lineages compared with other features, e.g., apical bulb on Ant. IV [34]. As a result of a phylogenetic analysis of Lepidocyrtus from Puerto Rico, the dental tubercle appeared to be one of the features with relatively high retention index, and thus appropriate as subgeneric diagnostic character for Neotropical species, but mostly combined with other characters [35]. Since the abovementioned studies are relevant to confined geographical regions only, several authors have advocated the need for extended molecular analyses to help discriminate genera of Lepidocyrtinae (e.g., $[34,35,56])$. In the original description, based on the chaetotaxic similarity with other European species, the authors decided to place L. tomosvaryi in the subgenus Lanocyrtus [27], which is strongly supported by the present molecular analyses.

A further character unique among European Lepidocyrtus, a tuft of numerous (up to 60) long filiform chaetae on the lateral part of Abd. III, was discovered in L. peisonis when performing a detailed redescription by Winkler and Mateos [40]. This character has been described for certain species 
belonging to the subgenera Setogaster and Cinctocyrtus, but it was virtually unknown for European species of the subgenera Lanocyrtus and Lepidocyrtus s.str. With scales on the antennae, legs and dorsal surface of manubrium, the species L. peisonis belongs to the subgenus Lepidocyrtus s.str. In contrast, both Cinctocyrtus and Setogaster are characterized by lack of scales on the abovementioned regions and the presence of rounded dental tubercle [32,39]. An additional important character for Setogaster is the presence of an accessorial spinelet on the basal mucronal spine [9,39,59]. Our molecular data clearly placed L. peisonis in the subgenus Lepidocyrtus s.str., within the lignorum-group, showing that the lateral tuft alone is not regarded as a decisive character at subgeneric level and should be taken into account in combination with other characters.

Corroborating with the result of Mateos et al. [13], the 15 European species examined in our study can be classified either within the subgenus Lepidocyrtus s.str. or Lanocyrtus. Our molecular analyses also confirmed the monophyly of the subgenus Lepidocyrtus s.str. and the paraphyly of Lanocyrtus.

\subsection{Lepidocyrtus Species Groups}

The molecular analyses gave us the opportunity to confirm the validity of the major Lepidocyrtus species-groups created on the base of morphological characters (see the key in [13], p. 649). The lanuginosus-group, represented by L. cyaneus and L. lanuginosus in our study, was strongly supported by the genetic datasets, supporting the results obtained by Mateos et al. [13]. With respect to the pallidus-serbicus-group, its monophyly has only been suggested by the EF1- $\alpha$ dataset. However, it was not sufficiently supported. COII and concatenated (COII and EF1- $\alpha$ ) datasets classified the species bearing cephalic macrochaetae $\mathrm{A}_{0} \mathrm{~A}_{2} \mathrm{~A}_{3} \mathrm{M}_{2} \mathrm{~S}_{3} \mathrm{~Pa}_{5}$ and with body macrochaetae formula 00/0101+2 (L. isabelleae, L. serbicus and L. tomosvaryi) into a strongly supported monophyletic clade, while the species L. arrabonicus and L. florae, having the same body macrochaetae formula but reduced number of head macrochaetae $\left(\mathrm{A}_{0} \mathrm{~A}_{2} \mathrm{~A}_{3} \mathrm{~Pa}_{5}\right.$ and $\mathrm{A}_{0} \mathrm{~A}_{2} \mathrm{~A}_{3} \mathrm{~S}_{3} \mathrm{~Pa}_{5}$, respectively), were clustered in a highly supported separated clade in the COII tree (in the concatenated tree, a single sequence of L. florae represented a separate clade, since EF1- $\alpha$ sequences of L. arrabonicus were unfortunately not available).

Nevertheless, dorsal head macrochaetotaxy can be variable within species groups, as a recently described species, L. intermedius (Mateos, Escuer \& Álvarez-Presas, 2018), with dorsal head macrochaetae $\mathrm{A}_{0} \mathrm{~A}_{2} \mathrm{~Pa}_{5}$ typical for the curvicollis-group, was clearly placed within the lignorum-group in the phylogenetic analysis carried out by Mateos et al. [13]. It can therefore be stated that dorsal head macrochaetotaxy is not suitable for species-group differentiation, and for this very reason, extended analyses involving more species and more genes will probably verify the validity of the pallidus-serbicus-group as well. In the concatenated dataset, the strongly supported curvicollis-group, appearing as a sister clade with the lignorum-group, is further divided into two subclades. The connection between the species L. curvicollis and L. mariani might be derived from the presence of additional pseudopores on Abd. IV: in dorsolateral (L. curvicollis) and lateral position (L. mariani), which supports the suggestion by Deharveng et al. [60], according to which the number and distribution of pseudopores may have high taxonomic importance.

Within the lignorum-group, based on the concatenated datasets, specimens of the two sampled L. peisonis populations are grouped in a separate subclade. Apart from the lateral tuft of filiform chaetae, the other unique character among the studied species is the truncated unguiculus of this species (see Table 2). The shape of the unguiculus was one of the phylogenetically important characters in Soto-Adames' analyses of Neotropical Lepidocyrtus [35]. Whether the separation of L. peisonis within the lignorum-group is derived from either of the abovementioned characters remains an open question.

\subsection{Cryptic Species}

As several authors have already pointed out, the species richness of Lepidocyrtus is most likely highly underestimated due to the presence of cryptic species that cannot be delimited and diagnosed using traditional morphological characters [11-15,61]. Based on our molecular datasets, several cryptic species were detected in the lignorum-group. In the COII tree, specimens determined as L. lignorum 
were classified in two different clades. At the same time, specimens identified as L. peisonis appeared separately in three different clades in all phylogenetic trees. The obtained K2P and p-distance values (Tables S2 and S3) were way above the mean intraspecific values reported by Zhang et al. (2018) and Mateos et al. (2018) for the species of the genus ( $0 \%-7.0 \%$ for K2P and $0 \%-6.5 \%$ for p-distance, respectively), confirming cryptic species status. Nevertheless, consideration should be given to the revision of rarely considered or overlooked characters for these species, including, e.g., the number, type, and distribution of S-chaetae [62], or the number and distribution of pseudopores [60].

\section{Conclusions}

The present molecular study brought new insight into the phylogeny of European Lepidocyrtus. One of the key characters in delimiting subgenera, the dental tubercle, has been proven to be not determinative in delineating monophyletic lineages. Based on the morphological pecularities, L. tomosvaryi, the only European species possessing a dental tubercle, would more likely belong to the Cinctocyrtus subgenus. Nevertheless, our molecular analyses clearly placed this species within a clade composed of species lacking this feature but sharing the same body macrochaetotaxy and distribution of scales, thus belonging to the subgenus Lanocyrtus.

The molecular phylogeny confirmed the monophyly of the subgenus Lepidocyrtus s.str. and the paraphyly of Lanocyrtus. European species groups established for the genus on the basis of morphological characters were only confirmed in part. The splitting of the pallidus-serbicus-group in the COII and concatenated trees requires further analysis involving extended material and genes to clarify the validity of this group.

Supplementary Materials: The following are available online at http://www.mdpi.com/2075-4450/11/5/302/s1, Table S1: GenBank accession numbers for nucleotide sequences generated for this study; Table S2: Pairwise distance matrix (uncorrected p-distances, \%) for COII sequences; Table S3: Pairwise distance matrix (K2P, \%) for COII sequences.

Author Contributions: Conceptualization, all authors; methodology, D.W., E.M., F.L., V.T.; software, V.T.; formal analysis, all authors; investigation, all authors; resources, D.W., G.T., F.L., V.T.; data curation, D.W., F.L., V.T.; writing-original draft preparation, D.W., E.M., F.L., V.T.; writing-review and editing, D.W.; visualization, D.W., V.T.; supervision, all authors; project administration, F.L.; funding acquisition, F.L. All authors have read and agreed to the published version of the manuscript.

Funding: The work of D.W., F.L. and V.T. was supported by the project EFOP-3.6.2-16-2017-00018 at the University of Sopron.

Acknowledgments: We would like to thank our colleagues Ágnes Csiszár, Petra Kelemen, Ádám Erdő and József Selyem (University of Sopron) for their cooperation on the sample material collection trips, and Katalin Fehér for the help in the laboratory work.

Conflicts of Interest: The authors declare no conflict of interest.

\section{References}

1. Yoshii, R. Lepidocyrtid Collembola of Sabah. Entomol. Rep. Sabah For. Res. 1982, 5, 1-47.

2. Deharveng, L. Recent advances in Collembola systematics. Pedobiologia 2004, 48, 415-433. [CrossRef]

3. Bellinger, P.F.; Christiansen, K.A.; Janssens, F. Checklist of the Collembola of the World. Available online: http://www.collembola.org (accessed on 14 February 2020).

4. Winkler, D. A new species of Lepidocyrtus (Collembola, Entomobryidae) from the Börzsöny Mountains, Hungary. Zootaxa 2016, 4150, 388-400. [CrossRef]

5. Querner, P.; Milasowszky, N.; Zulka, K.P.; Abensperg-Traun, M.; Willner, W.; Sauberer, N.; Jakomini, C.; Wrbka, T.; Schmitzberger, I.; Zechmeister, H.G. Habitat Structure, Quality and Landscape Predict Species Richness and Communities of Collembola in Dry Grasslands in Austria. Insects 2018, 9, 81. [CrossRef]

6. Dányi, L. Cave dwelling springtails (Collembola) of Hungary: A review. Soil Org. 2011, 83, 419-432.

7. Fiera, C.; Habel, J.C.; Ulrich, W. Neutral colonisations drive high beta-diversity in cavernicole springtails (Collembola). PLoS ONE 2018, 13, e0189638. [CrossRef] 
8. Arbea, J.I.; Jordana, R. New species of Pseudosinella and Lepidocyrtus from Navarra (Northern Iberian Peninsula). Spixiana 1989, 13, 25-31.

9. Cipola, N.G.; de Morais, J.W.; Bellini, B.C. New subgenus and four species of Lepidocyrtus Bourlet (Collembola, Entomobryidae, Lepidocyrtinae) from Amazon. Insect Syst. Evol. 2018, 4027, 189-234. [CrossRef]

10. Traser, G.; Christian, E. Lepidocyrtus peisonis sp. n., ein neuer Springschwanz aus dem Neusiedlersee-Gebiet (Collembola: Entomobryidae). Folia Entomol. Hung. 1992, 52, 119-121.

11. Cicconardi, F.; Nardi, F.; Emerson, B.C.; Frati, F.; Fanciulli, P.P. Deep phylogeographic divisions and long-term persistence of forest invertebrates (Hexapoda: Collembola) in the North-Western Mediterranean basin. Mol. Ecol. 2010, 19, 386-400. [CrossRef]

12. Cicconardi, F.; Fanciulli, P.P.; Emerson, B.C. Collembola, the biological species concept and the underestimation of global species richness. Mol. Ecol. 2013, 22, 5382-5396. [CrossRef] [PubMed]

13. Mateos, E.; Escuer, P.; Busmachiu, G.; Riutort, M.; Álvarez-Presas, M. Untangling Lepidocyrtus (Collembola, Entomobryidae): New molecular data shed light on the relationships of the European groups. Invertebr. Syst. 2018, 32, 639-651. [CrossRef]

14. Zhang, B.; Chen, T.W.; Mateos, E.; Scheu, S.; Schaefer, I. Cryptic species in Lepidocyrtus lanuginosus (Collembola: Entomobryidae) are sorted by habitat type. Pedobiologia 2018, 68, 12-19. [CrossRef]

15. Zhang, B.; Chen, T.W.; Mateos, E.; Scheu, S.; Schaefer, I. DNA-based approaches uncover cryptic diversity in the European Lepidocyrtus lanuginosus species group (Collembola: Entomobryidae). Invertebr. Syst. 2019, 33, 661-670. [CrossRef]

16. Gisin, H. Collembolenfauna Europas; Museum d'Histoire Naturelle: Genève, Switzerland, 1960; pp. 1-312.

17. Gisin, H. Collemboles d'Europe. VI. Rev. Suisse Zool. 1964, 71, 383-400. [CrossRef]

18. Gisin, H. Collemboles d'Europe VII. Rev. Suisse Zool. 1964, 71, 649-678.

19. Gisin, H. Nouvelles notes taxonomiques sur les Lepidocyrtus. Rev. Ecol. Biol. Sol 1965, 2, 519-524.

20. Gisin, H. La systématique idéale. J. Zool. Syst. Evol. Res. 1967, 5, 111-128. [CrossRef]

21. Szeptycki, A. Morpho-systematic studies on Collembola III. Body chaetotaxy in the first instars of several genera of the Entomobryomorpha. Acta Zool. Cracov. 1972, 17, 341-372.

22. Szeptycki, A. Chaetotaxy of the Entomobryidae and its Phylogenetical Significance. Morpho-Systematic Studies of Collembola, IV; Polska Akademia Nauk, Zakład Zoologii Systematycznej i Doświadczalnej: Kraków, Poland, 1979; pp. 1-219.

23. Mateos, E. Definition of Lepidocyrtus lusitanicus Gama, 1964 species-complex (Collembola, Entomobryidae), with description of new species and color forms from the Iberian Peninsula. Zootaxa 2008, 1917, 38-54. [CrossRef]

24. Mateos, E. New Lepidocyrtus Bourlet, 1839 taxa from Greece (Collembola: Entomobryidae). Zootaxa 2011, 3108, 25-40. [CrossRef]

25. Mateos, E. The European Lepidocyrtus lanuginosus group (Collembola: Entomobryidae), definition and description of a new species from Spain. Zootaxa 2012, 3570, 69-81. [CrossRef]

26. Mateos, E.; Petersen, H. Definition of the European Lepidocyrtus curvicollis group (Collembola: Entomobryidae) with description of a new species from Sardinia (Italy). Zootaxa 2012, 3273, 51-62. [CrossRef]

27. Winkler, D.; Traser, G. Explanation of the European Lepidocyrtus pallidus-serbicus group (Collembola, Entomobryidae), with description of new species from Hungary. Zootaxa 2012, 3394, 35-47. [CrossRef]

28. Mateos, E.; Winkler, D. New data clarifying the taxonomy of European members of the Lepidocyrtus pallidus-serbicus group (Collembola, Entomobryidae). Zootaxa 2018, 4429, 548-568. [CrossRef] [PubMed]

29. Salmon, J.T. Keys and Bibliography to the Collembola. Zool. Pub. Victoria Univ. College 1951, 8, 1-81.

30. Yosii, R. Studies on the Collembolan fauna of Malay and Singapore. Contrib. Biol. Lab. Kyoto Univ. 1959, 10, 1-65.

31. Yosii, R. On some Collembola of Hindukush with notes on Isotoma and its allies. Res. Kyoto Univ. Sci. Exp. Karakoram Hindukush 1963, 4, 3-42.

32. Yoshii, R.; Suhardjono, Y.R. Notes on the Collembolan Fauna of Indonesia and its vicinities. I. Miscellaneous Notes, with special references to Seirini and Lepidocyrtini. AZAO 1989, 1, 23-90.

33. Ma, Y. Two new species of Lepidocyrtus Bourlet s. lat. (Collembola: Entomobryidae) from China. Eur. J. Taxon. 2019, 565, 1-121. [CrossRef]

34. Christiansen, K.A.; Bellinger, P.F. Phylogeny of the Hawaiian Species of the Genus Lepidocyrtus (Collembola, Entomobryidae). Rev. Ecol. Biol. Sol. 1991, 28, 207-215. 
35. Soto-Adames, F.N. Phylogeny of Neotropical Lepidocyrtus (Collembola: Entomobryidae): First assessment of patterns of speciation in Puerto Rico and phylogenetic relevance of some subgeneric diagnostic characters. Syst. Entomol. 2000, 25, 485-502. [CrossRef]

36. Wang, F.; Chen, J.-X.; Christiansen, K. Taxonomy of the genus Lepidocyrtus s.l. (Collembola: Entomobryidae) in East and Southeast Asia and Malaysia, with description of a new species from the People's Republic of China. Can. Entomol. 2003, 135, 823-837. [CrossRef]

37. Mateos, E. The European Lepidocyrtus Bourlet, 1839 (Collembola: Entomobryidae). Zootaxa 2008, 1769, 35-59. [CrossRef]

38. Yoshii, R.; Suhardjono, Y.R. Collembolan fauna of Indonesia and its affinities. II: Collembola of Irian Jaya and Maluku Island. Acta Zool. Asiae Orient. 1992, 2, 1-52.

39. Mateos, E.; Greenslade, P. Towards understanding Lepidocyrtus Bourlet, 1839 (Collembola, Entomobryidae) I: Diagnosis of the subgenus Setogaster, new records and redescriptions of species. Zootaxa 2015, 4044, 105-129. [CrossRef]

40. Winkler, D.; Mateos, E. Redescription of Lepidocyrtus peisonis Traser \& Christian, 1992 with notes on Lepidocyrtus mariani Traser \& Dányi, 2008 (Collembola: Entomobryidae). Zootaxa 2018, 4375, 392-408. [CrossRef]

41. Arbea, I.; Jordana, R. Colémbolos de las Islas Baleares (Insecta, Collembola). Redia 1990, 73, 187-200.

42. Bonnet, L.; Cassagnau, P.; Deharveng, L. Recherche d'une méthodologie dans l'analyse de la rupture des équilibres biocénotiques: Application aux Collemboles édaphiques des Pyrénées. Rev. Ecol. Biol. Sol. 1979, $16,373-401$.

43. Thompson, J.D.; Gibson, T.J.; Plewniak, F.; Jeanmougin, F.; Higgins, D.G. The Clustal_X Windows interface: Flexible strategies for multiple sequence alignment aided by quality analysis tools. Nucleic Acids Res. 1997, 25, 4876-4882. [CrossRef]

44. Kimura, M. A simple method for estimating evolutionary rate of base substitutions through comparative studies of nucleotide sequences. J. Mol. Evol. 1980, 16, 111-120. [CrossRef] [PubMed]

45. Tamura, K.; Peterson, D.; Peterson, N.; Stecher, G.; Nei, M.; Kumar, S. MEGA5: Molecular evolutionary genetics analysis using maximum likelihood, evolutionary distance, and maximum parsimony methods. Mol. Biol. Evol. 2011, 28, 2731-2739. [CrossRef] [PubMed]

46. Delamare-Deboutteville, C. Recherches sur les Collemboles termitophiles et myrmécophiles (Ecologie, Ethologie, Systématique). Archs. Zool. Exp. Gen. 1948, 85, 261-425.

47. Darriba, D.; Taboada, G.L.; Doallo, R.; Posada, D. jModelTest 2: More models, new heuristics and parallel computing. Nat. Methods 2012, 9, 772. [CrossRef] [PubMed]

48. Guindon, S.; Gascuel, O. A simple, fast and accurate method to estimate large phylogenies by maximum-likelihood. Syst. Biol. 2003, 52, 696-704. [CrossRef] [PubMed]

49. Akaike, H. A new look at the statistical model identification. IEEE Trans. Automat. Contr. 1974, 19, 716-723. [CrossRef]

50. Nguyen, L.-T.; Schmidt, H.A.; von Haeseler, A.; Minh, B.Q. IQ-TREE: A fast and effective stochastic algorithm for estimating maximum likelihood phylogenies. Mol. Biol. Evol. 2015, 32, 268-274. [CrossRef]

51. Ronquist, F.; Teslenko, M.; Van Der Mark, P.; Ayres, D.L.; Darling, A.; Höhna, S.; Larget, B.; Liu, L.; Suchard, M.A.; Huelsenbeck, J.P. MrBayes 3.2: Efficient Bayesian phylogenetic inference and model choice across a large model space. Syst. Biol. 2012, 61, 539-542. [CrossRef]

52. Rambaut, A.; Drummond, A.J.; Xie, D.; Baele, G.; Suchard, M.A. Posterior summarisation in Bayesian phylogenetics using Tracer 1.7. Syst. Biol. 2018, 67, 901-904. [CrossRef]

53. Rambaut, A. FigTree, ver. 1.4.4. Available online: http://tree.bio.ed.ac.uk/software/figtree/ (accessed on 12 December 2019).

54. Varga, Z. Extra-Mediterranean Refugia, Post-Glacial Vegetation History and Area Dynamics in Eastern Central Europe. In Relict Species-Phylogeography and Conservation Biology; Habel, J.C., Assmann, T., Eds.; Springer: Heidelberg, Germany, 2010; pp. 57-87.

55. Dányi, L.; Traser, G. Springtails of Hungary. In The Origin of the Fauna of the Carpathian Basin; Forró, L., Ed.; Hungarian Natural History Museum: Budapest, Hungary, 2007; pp. 21-28.

56. Winkler, D. New Lepidocyrtus Bourlet, 1839 from riverine woodland in Hungary (Collembola, Entomobryidae). Zootaxa 2017, 4250, 529-540. [CrossRef] 
57. Mari Mutt, J.A. Puerto Rican species of Lepidocyrtus and Pseudosinella (Collembola: Entomobryidae). Caribb. J. Sci. 1986, 22, 1-48.

58. Xu, G.-L.; Pan, Z.-H.; Zhang, F. First record of Acrocyrtus Yosii, 1959 (Collemobla, Entomobryidae) from Chinese mainland. ZooKeys 2013, 260, 1-16. [CrossRef]

59. Handschin, E. Hygrophile Collembolen aus Niederländische-Indian. Arch. Hydrobiol. 1932, 9, 472-490.

60. Deharveng, L.; Jantarit, S.; Bedos, A. Revisiting Lepidonella Yosii (Collembola: Paronellidae): Character overview, checklist of world species and reassessment of Pseudoparonella doveri Carpenter. Ann. Soc. Entomol. Fr. 2018, 54, 381-400. [CrossRef]

61. Soto-Adames, F.N. Molecular phylogeny of the Puerto Rican Lepidocyrtus and Pseudosinella (Hexapoda: Collembola), a validation of Yoshii's 'colour pattern species'. Mol. Phylogenet. Evol. 2002, 25, 27-42. [CrossRef]

62. Zhang, F.; Deharveng, L. Systematic revision of Entomobryidae (Collembola) by integrating molecular and new morphological evidence. Zool. Scr. 2015, 44, 298-311. [CrossRef]

(C) 2020 by the authors. Licensee MDPI, Basel, Switzerland. This article is an open access article distributed under the terms and conditions of the Creative Commons Attribution (CC BY) license (http://creativecommons.org/licenses/by/4.0/). 